\title{
EDITORIAL
}

\section{New Knowledge for and About Primary Care: A View Through the Looking Glass of the Annals of Family Medicine}

\author{
William L. Miller, MD, MA, William R. Pbillips, MD, MPH, Louise S. Acbeson, MD, MS, \\ Benjamin F. Crabtree, PbD, Stepben J. Zyzanski, PbD, Paul A. Nutting, MD, MSPH, Robin S. Gotler, MA, \\ Laura A. McLellan, MLS, Kurt C. Stange, MD, PbD \\ Ann Fam Med 2005;3:197. DOI: 10.1370/afm.330.
}

$\mathrm{T}$ The Annals of Family Medicine began publication 2 years ago to provide a forum for new kinds of knowledge, new ways of generating knowledge, and new ways of sharing information across the traditional boundaries of profession, role or geography. ${ }^{1}$ In a special article, which can be found online as a supplemental article at http://www.annfammed.org/cgi/ content/full/3/3/197/DC1, the editors analyze the ing content of the first 2 volumes. We recognize the small slice of the primary care research pie that is represented by the Annals. Nevertheless, this analysis attempts to identify how diverse authors and readers have used this forum to transmit and interact with new knowledge about health and primary care. From this analysis, we attempt to draw some larger lessons about the current state and future directions for primary care research.

The following text is the abstract to the supplemental special article:

\section{Purpose}

At this second anniversary of the Annals of Family Medicine, we sought to characterize primary care research and to identify opportunities for new directions by analyzing the content of the first and second volumes of the Annals.

\section{Methods}

Using an a priori classification scheme, 2 editors independently categorized each research article and essay published in 2003 and 2004, excluding supplements. We categorized the domain of knowledge, methods, topical content, whether articles represented core values of primary care, and looked for articles that studied health/illness/symptoms from a uniquely primary care experience. We reconciled differences by discussion.

\section{Results}

Among 110 articles, knowledge domains reflected the 4 quadrants of the clinician $(n=6)$, patient, family, or community (10), health care system (32), disease (22), or the interface (39) between these quadrants. The most frequent methods were cross-sectional studies (23), cohorts (15), randomized clinical trials (13), qualitative interviews (11), analyses of secondary data (11), systematic reviews (11), methods/theory development (10), self-reflections (8), and mixed methods (5). The most common topical areas were chronic disease and prevention. Core primary care values were represented in $75 \%$ of articles. Only 2 articles represented an integrative illness/healing perspective.

\section{Conclusions}

Despite contemporary forces driving a reductionistic approach, primary care research, as reflected by articles published in the Annals of Family Medicine, addresses the domains of knowledge that contribute to comprehensive, relationship-centered health care. More work is needed to understand the nature of health and illness in whole people and ways to integrate diverse knowledge, methods and fragmented health care.

To read or post commentaries in response to this article, see it online at http://www.annfammed.org/cgi/content/full/3/3/197.

\section{Reference}

1. Stange KC, Phillips WR, Acheson LS, et al. Welcome to the Annals of Family Medicine. Ann Fam Med. 2003;1:2-4. 